\title{
Deficient Classical Complement Pathway Activity in Newborn Sera
}

\author{
MORVEN S. EDWARDS, ${ }^{(23,24)}$ GREGORY J. BUFFONE, PAMELA A. FUSELIER, JANIS L. WEEKS, \\ AND CAROL J. BAKER ${ }^{(22,24)}$ \\ Departments of Pediatrics, Myers-Black Section of Infectious Diseases, Microbiology and Immunology, and \\ Pathology, Baylor College of Medicine, Houston, Texas, USA
}

\begin{abstract}
Summary
The bactericidal activity of 20 maternal-neonatal paired sera was assessed employing a clinical type Ia, group B streptococcal isolate, strain 515, known to be opsonized by the classical complement pathway in a non-antibody dependent fashion. Twelve neonatal sera had efficient bactericidal activity for this isolate (mean 96\%, range $91-99 \%$ ) whereas eight had significantly lower bactericidal indices (mean $29 \%$, range $0-54 \%)(p<0.001)$. The mean bactericidal index for 20 maternal sera $(88 \%)$ did not differ from that of 20 adult control sera $(91 \%)$. Bactericidal activity was not influenced by the concentration of antibody to the capsular polysaccharide antigen of type Ia, group B Streptococcus present in these sera. When the classical pathway of selected neonatal sera with high or low bactericidal activity was inactivated by MgEGTA chelation of $\mathrm{C1}$, bacterial growth was observed uniformly when concentrations of specific antibody were low. The bactericidal index of neonatal sera correlated significantly with the total hemolytic complement titer $(r=0.611, P<0.01)$. The mean levels of each complement component or control protein assessed by radial immunodiffusion ( $\mathrm{Clq}, \mathrm{C} 4, \mathrm{C} 3, \mathrm{~B}, \mathrm{H}$, and $\mathrm{I})$ were lower in neonatal sera with low than in those with efficient bactericidal activity, and levels of $\mathrm{Clq}$ and $\mathrm{H}$ were depressed significantly ( $P$ $<0.025$ and $<0.001$, respectively). Hemolytic titers of $\mathrm{C} 4$ but not $\mathrm{C} 1$ or $\mathrm{C} 2$ were also significantly lower for low than for selected high-killing neonatal sera $(P<0.05)$. Bactericidal activity in neonatal serum with a bactericidal index of zero was restored in a dose-dependent fashion by the addition of fresh frozen plasma.
\end{abstract}

\section{Abbreviations}

BI, bactericidal index

$\mathrm{CH}_{50}$, whole complement activity

EGTA, ethyleneglycoltetracetate

FFP, fresh frozen plasma

GVB, Veronal-buffered saline containing $0.1 \%$ gelatin

$\mathrm{GVB}^{++}$, GVB containing $0.5 \mathrm{mM} \mathrm{Mg}{ }^{++}$and $0.15 \mathrm{mM} \mathrm{Ca}^{++}$

MgEGTA, GVB supplemented to $4 \mathrm{mM} \mathrm{Mg}^{++}$and $16 \mathrm{mM}$ EGTA

adjusted to $\mathrm{pH} 7.5$

OD, optical density

THB, Todd-Hewitt broth

The levels of individual classical complement pathway components in neonatal sera have been shown to be significantly lower than those in adults $(1,6-7,11-12,19)$. Davis et al. (6) have shown that by the age of 6 months the mean concentrations of $\mathrm{C} 2$ and $\mathrm{C} 4$ have increased to levels not significantly different from those of adults, but $\mathrm{Clq}$ and $\mathrm{C} 3$ concentrations remain low. Few studies have compared the functional capacity of the classical pathway for a pathogen common in the neonate with the degree of depression of individual classical pathway components. We have shown previously that bactericidal activity in adult sera for a variety of clinical isolates of type Ia, group B streptococci was mediated by the classical complement pathway in a non-antibody dependent fashion (2). Both adult sera deficient in specific antibody and agammaglobulinemic serum, which had no detectable antibody to the capsular polysaccharide antigen of type Ia, group B Streptococcus supported efficient bactericidal activity for each of 18 clinical type Ia, group B streptococcal isolates tested. In contrast, after MgEGTA chelation of agammaglobulinemic serum, or when specific antibody-deficient $\mathrm{C} 2$-deficient serum was employed, bacterial growth resulted.

The present experiments were designed to examine the possibility that a deficiency in classical complement pathway function could be an important determinant of neonatal susceptibility to type Ia, group B streptococcal disease. The well-defined opsonic requirements of clinical isolates of type Ia, group B streptococci provided an excellent model whereby levels of classical complement components and functional assessment of total and classical pathway-mediated hemolysis could be correlated with bactericidal capacity for this important neonatal pathogen.

\section{MATERIALS AND METHODS}

Sera. Sera processed to preserve endogenous complement activity were collected by peripheral venipuncture from 20 healthy neonates less than $72 \mathrm{~h}$ of age and from their mothers after informed consent was obtained. Control serum was obtained from 20 healthy adults. Infants were 38-42 wk of gestation, of appropriate weight for gestational age, had APGAR scores of at least 8 at $5 \mathrm{~min}$, and had experienced an uncomplicated hospital course until the time of enrollment. Neonates with risk factors for infection (rupture of membranes more than $24 \mathrm{~h}$ before delivery, maternal peripartum fever or amnionitis) and those who had received antimicrobial therapy were excluded from study. Sera were stored in aliquots at $-70^{\circ} \mathrm{C}$ until use in bactericidal or complement assays.

Bacteria. Type Ia, group B streptococcal strain, 515, was isolated from the blood of an infected neonate. This strain has been shown previously to be representative among 18 fresh clinical type Ia, group B streptococcal isolates for which opsonophagocytic requirements were determined in agammaglobulinemic and normal adult sera (2). These strains required the classical complement pathway for opsonophagocytosis and were not dependent upon the presence of specific antibody for initiation of classical pathway activity. After primary isolation, bacteria were inoculated into THB (Difco Laboratories, Detroit, MI), incubated at $37^{\circ} \mathrm{C}$ overnight, and stored at $-70^{\circ} \mathrm{C}$ in $0.5 \mathrm{ml}$ aliquots.

For the bactericidal assay, a frozen aliquot was streaked onto a blood agar plate and incubated overnight at $37^{\circ} \mathrm{C}$. Plate-grown organisms then were inoculated into $\mathrm{THB}$ and grown for approximately $2 \mathrm{~h}$ to an OD of 0.22 at $540 \mathrm{~nm}$ (Spectronic 20, Bausch and Lomb, Inc., Rochester, NY). Cultures grown in this manner were in mid-log phase growth. Thirty $\mathrm{ml}$ of broth culture was centrifuged at $750 \times \mathrm{g}$ for $15 \mathrm{~min}$ at $4^{\circ} \mathrm{C}$, the pellet was resuspended in $16 \mathrm{ml}$ of minimal essential medium with Earle's bal- 
anced salt solution (Microbiological Associates, Walkersville, MD), and a 1:10 dilution of this bacterial suspension in minimal essential medium achieved a bacteria to neutrophil ratio of approximately $2: 1$ in the opsonic reaction mixture.

Antibody determination. Concentrations of antibody to native type Ia, group B streptococcal polysaccharide $(\mu \mathrm{g} / \mathrm{ml})$ were determined by a radioactive antigen binding assay as previously described (2)

Buffers. Isotonic, $\mathrm{pH} 7.5$, veronal- $\mathrm{NaCl}$ buffer containing $0.1 \%$ gelatin made to $0.15 \mathrm{mM} \mathrm{Ca}^{++}$and $0.5 \mathrm{mM} \mathrm{Mg}^{++}\left(\mathrm{GVB}^{++}\right)$was prepared as described previously (10). MgEGTA buffer was made by supplementing GVB to $4 \mathrm{mM} \mathrm{Mg}{ }^{++}$and $16 \mathrm{mM}$ EGTA and adjusting the $\mathrm{pH}$ to 7.5 . Dilution of serum 1:2 with MgEGTA to chelate calcium has been shown previously (10) to permit C3 activation by zymosan ( $85 \%$ consumption) but not by antibodycoated sheep erythrocytes.

Bactericidal assay. The methods for the bactericidal assay employed have been described previously in detail $(2,9,10)$. The opsonic reaction mixture contained $0.1 \mathrm{ml}$ of freshly harvested human leukocytes (approximately $1 \times 10^{6}$ neutrophils), $0.1 \mathrm{ml}$ of bacterial suspension (approximately $2 \times 10^{6}$ colony forming units), and $0.1 \mathrm{ml}$ of human serum containing endogenous complement. For experiments in which fresh frozen plasma $(0.1 \mathrm{ml})$ was added to the reaction mixture, the leukocyte and bacterial component concentrations were doubled and $0.05 \mathrm{ml}$ of each component employed in order to avoid altering the final concentration of serum. Each assay included control tubes lacking leukocytes, test serum or complement. Opsonic mixtures were incubated at $37^{\circ} \mathrm{C}$ with end-over-end rotation in a Roto-Rack apparatus (Fisher Scientific Co., Pittsburgh, PA) for $40 \mathrm{~min}$. When the classical pathway was inhibited by MgEGTA the procedure was modified to include a $30 \mathrm{~min}$ opsonization step at $37^{\circ} \mathrm{C}$ to avoid toxicity to the leukocytes. After centrifugation at $4^{\circ} \mathrm{C}$, the bacteria were resuspended in minimal essential medium with or without added leukocytes. The procedure then was completed as described previously $(9,10)$, and the reuslts were expressed as the BI:

$$
\mathrm{BI}(\%)=100-\left[\frac{\mathrm{CFU} \text { at } 40 \text { minutes }}{\mathrm{CFU} \text { at } 0 \text { minutes }} \times 100\right]
$$

The results represent the mean of a minimum of two determinations unless otherwise indicated.

Complement assays. Levels of C1q, C4, C3, B, H, and I were determined by radial immunodiffusion using the method of Mancini et al. (14). Antisera to complement proteins Clq, C4, C3, B, and $\mathrm{H}$ were obtained from Atlantic Antibodies (Scarborough, $\mathrm{ME}$ ) and antisera to I was purchased from the laboratory of Dr. Clark West (Cincinnati, OH). Levels are expressed as the \% of an adult normal serum pool. Whole complement activity, $\mathrm{CH}_{50}$, was measured by a standard hemolytic assay (15). Stable cellular intermediates obtained from Cordis Corporation (Miami, FL) were employed to determine hemolytic $\mathrm{Cl}, \mathrm{C} 4$, and $\mathrm{C} 2$ titers, and the results are expressed as the $\%$ of an adult normal titer.

\section{RESULTS}

The bactericidal activity of maternal, neonatal and adult control sera for type Ia, group B Streptococcus, is summarized graphically in Figure 1. Sera from 12 neonates had high bactericidal capacity (mean BI 96\%, range 91-99\%), while eight neonatal sera had significantly lower bactericidal capacity (mean BI $29 \%$, range $0-$ $54 \%),(t=13.0, P<0.001$, unpaired $t$ test $)$. The mean bactericidal activity of maternal sera $(88 \%)$ did not differ significantly from that of healthy adult controls $(91 \%)(t=0.8, P=$ N.S.). Excluding one neonate who had a high concentration of serum antibody to the type Ia, group B streptococcal capsular antigen $(24.6 \mu \mathrm{g} / \mathrm{ml})$, the mean antibody levels for high compared with low BI neonatal sera were identical $(2.1 \mu \mathrm{g} / \mathrm{ml})$ and the ranges were similar (1.9$3.2 \mu \mathrm{g} / \mathrm{ml}$ and $1.9-2.7 \mu \mathrm{g} / \mathrm{ml}$ for high and low BI sera, respectively).

The possibility that an intact classical pathway might be re-

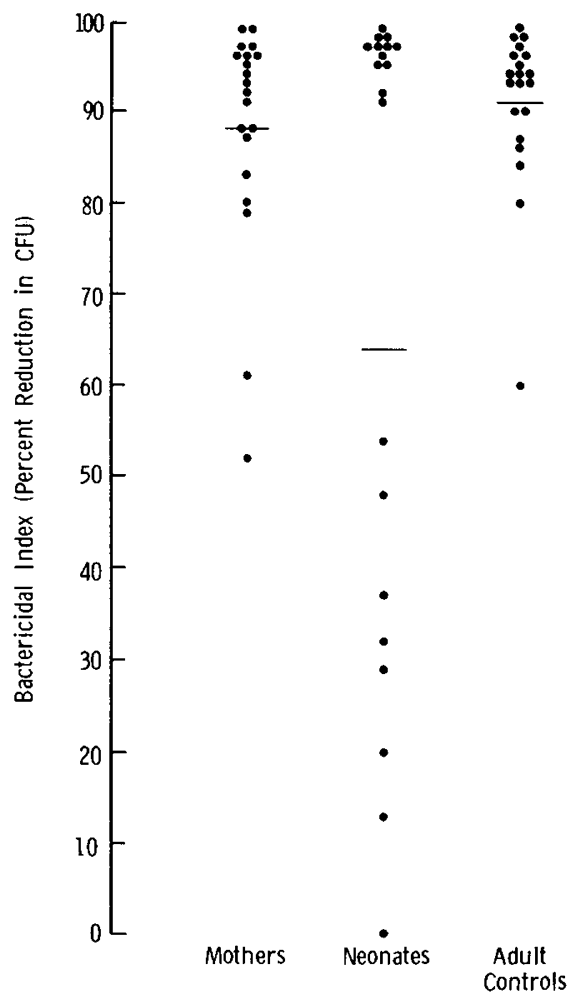

Fig. 1. Bactericidal activity for type Ia, group B streptococcal strain 515 by maternal, neonatal, and adult control sera. Each point represents the mean bactericidal index for one serum tested in a minimum of two experiments. The horizontal line indicates the mean bactericidal activity for 20 sera.

quired for bactericidal killing of type Ia, group B streptococci by neonatal sera then was investigated. The sera selected for study included that from the single neonate with a high concentration of antibody to the type Ia, group B streptococcal polysaccharide antigen, sera from four neonates with high bactericidal indices, and sera from three with deficient killing of these organisms (Fig. 1). When classical pathway $\mathrm{Cl}$ was inactivated by MgEGTA chelation, bacterial growth was observed for all sera except the single specimen with a high specific antibody concentration. This high specific antibody-containing serum recruited the alternative pathway poorly (BI $30 \%$, mean of three experiments) compared to the paired maternal control, which had a mean alternative pathway-mediated BI of $82 \%$. These results indicate that in specific antibody-deficient neonatal sera, an intact classical complement pathway is required for bactericidal activity to occur.

The mean $\mathrm{CH}_{50}$ for the 12 high BI neonatal sera (300, range 225-366 units) was significantly greater than that of the seven low BI neonatal sera available for testing (mean 227, range 195-278 units) $(P<0.01)$, and a significant correlation existed between $\mathrm{CH}_{50}$ and bactericidal activity $(r=0.611, P<0.01)$. The correlation between $\mathrm{CH}_{50}$ and birth weight was not significant $(r=0.283$, $P>0.05$ ). In order to exclude technique of serum collection as an explanation for this difference, $\mathrm{CH}_{50}$ s were determined for maternal sera processed concurrently with their infants. The mean $\mathrm{CH}_{50}$ for all mothers of low BI neonates (481, range 324-627 units) was not significantly different from that of selected mothers of high BI neonates (mean 493, range 363-592 units).

Neonatal sera with low bactericidal activity had lower mean levels of each classical or alternative pathway component and control protein assessed than neonatal sera with a bactericidal index in excess of $75 \%$ (Fig. 2). Levels of $\mathrm{Clq}$ and $\mathrm{H}$ were significantly lower in low BI neonatal sera $(P<0.03$ and $P<$ 0.01 , respectively). Functional assessment of classical pathway components $\mathrm{C} 1, \mathrm{C} 4$ and $\mathrm{C} 2$, performed for seven low $\mathrm{Bl}$ neonatal sera and three representative high BI neonatal sera (Fig. 3) 


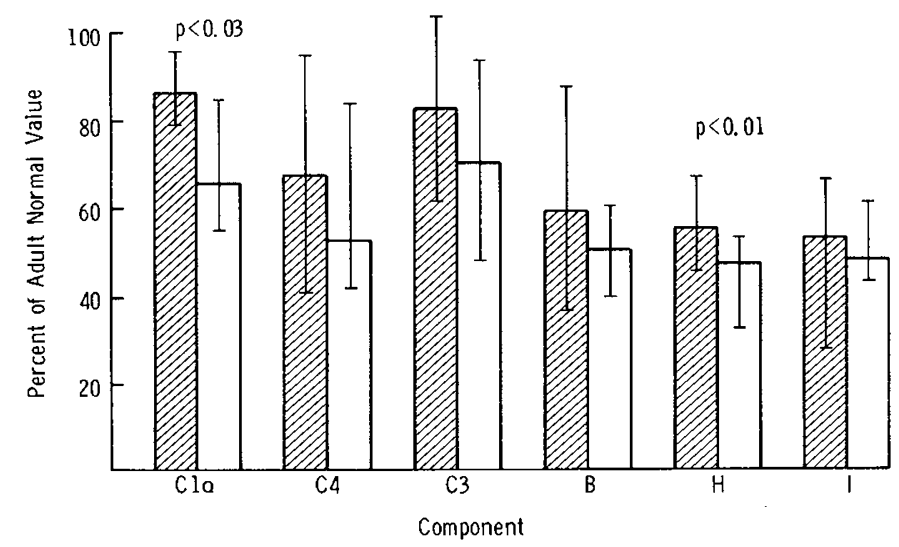

Fig. 2. The mean and range in complement component levels assessed by radial immunodiffusion for neonatal sera with high (hatched bars) or low (open bars) bactericidal indices for type Ia, group B Streptococcus:

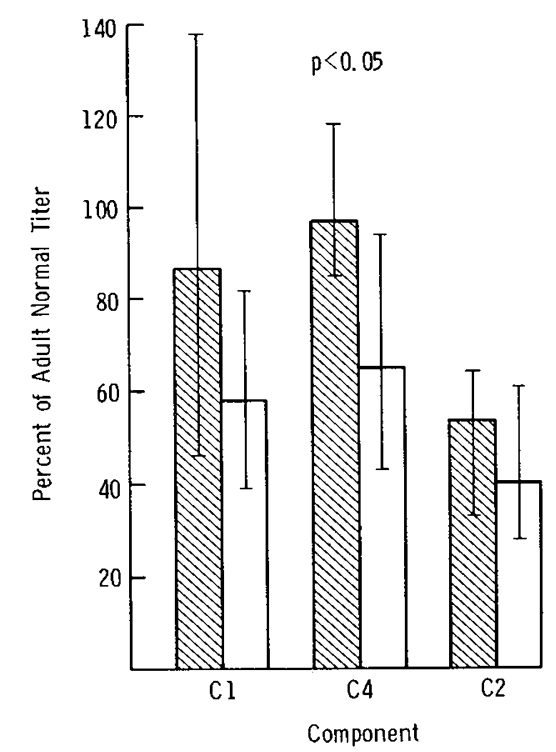

Fig. 3. The mean and range of classical pathway component hemolytic titers for selected neonatal sera with high (hatched bars) or low (open bars) bactericidal indices for type Ia, group B Streptococcus.

revealed lower titers of each component in the low BI sera. Titers of $\mathrm{C} 4$ were depressed significantly in low BI neonatal sera $(P<$ 0.05 ). The small number of sera available for study may have precluded the attainment of significance for the difference in $\mathrm{Cl}$ hemolytic titers.

Defibrinated FFP ( $\mathrm{CH}_{50}$ titer, 300 units) was employed as a complement source in an attempt to reconstitute bactericidal activity to a neonatal serum with no bactericidal activity (BI, $0 \%$ ). The FFP contained a very low concentration of antibody to the type Ia, Group B streptococcal polysaccharide $(3.1 \mu \mathrm{g} / \mathrm{ml})$. In the absence of serum, FFP had a BI greater than $90 \%$ to a dilution of 1:8 (Fig. 4); however, addition of FFP at dilutions of greater than or equal to $1: 16$ in $\mathrm{GVB}^{++}$restored bactericidal activity in a dosedependent fashion to serum with no bactericidal activity.

\section{DISCUSSION}

The preceding observations indicated that some sera from healthy term neonates (40\%) had markedly deficient bactericidal activity when tested using a strain of type Ia, group B Streptococcus (515) known to be effectively opsonized via the classical complement pathway in a non-antibody dependent fashion. In contrast the majority of neonatal sera had normal bactericidal activity when compared with paired maternal and control sera. Deficient

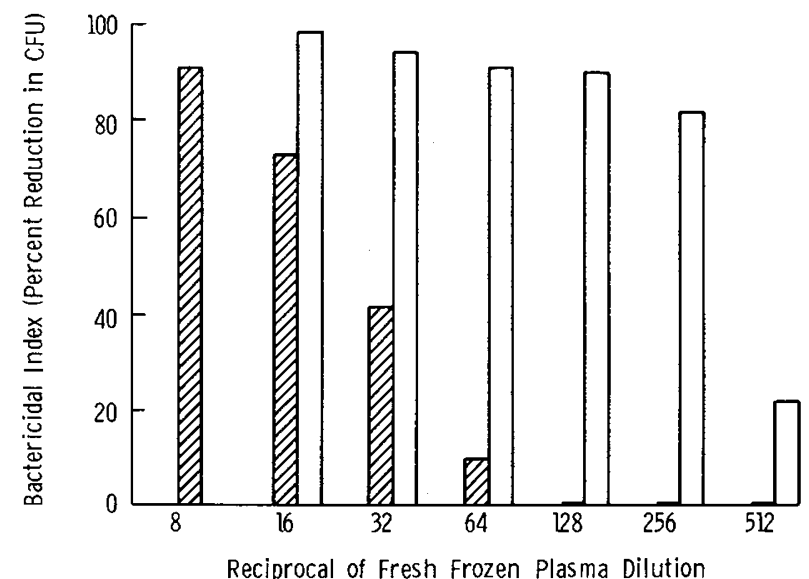

Fig. 4. The bactericidal index of fresh frozen plasma ( pressed as a function of its reciprocal dilution in saline. The bactericidal activity of neonatal serum with no intrinsic killing capacity following restoration with fresh frozen plasma at the dilutions indicated on the abscissa is shown ( $\square$ ).

bactericidal activity was unrelated to the concentration of specific antibody present in these sera, but correlated significantly with low total hemolytic complement titers and depressed Clq and $\mathrm{C} 4$ levels.

Strunk et al. (18) have demonstrated that the classical and the alternative pathway activation sequences are deficient to the same degree in newborn compared with adult sera. But previous studies in which the degree of depression of complement function in neonatal sera was related to deficient opsonization of a bacterial particle have shown that alternative rather than classical pathway opsonic function was defective. For example, Stossel et al. (17) demonstrated a correlation between markedly defective opsonic activity for Escherichia coli lipopolysaccharide-coated paraffin oil particles in $15 \%$ of cord sera and subnormal levels of factor B. Employing strains of $E$. coli which required the classical pathway for opsonization, Mills et al. (16) found that opsonic activity was comparable in neonatal sera to that of paired maternal and adult controls, whereas opsonization of strains which required the alternative pathway was depressed significantly in neonatal sera.

Because activation of the classical pathway by bacteria generally requires the participation of antibody (20), the recognition that a variety of clinical type Ia, group B streptococcal isolates were opsonized by the classical pathway in a non-antibody fashion (2) provided a unique opportunity to evaluate the functional integrity of the classical pathway in neonatal sera without antibody as a confounding variable. The type Ia, group B streptococcal isolate employed in the present studies promoted significant consumption of $\mathrm{C} 4$ and $\mathrm{C} 3$ and efficiently transferred $\mathrm{Cl}$ in the presence of agammaglobulinemic serum as a complement source (8). In contrast to other bacteria for which antibody-independent classical pathway activation has been described (for example, the galactose epimerase-deficient mutant $E$. coli $\mathrm{J} 5(3,4)$, and serum-sensitive Klebsiella pneumoniae strains (13), and a wild type and mutant strains of Salmonella minnesota (5)) this mechanism of complement activation is common to each of wide variety of clinical type Ia, group B streptococcal isolates tested (2). With the exception of one maternal-neonatal serum pair which contained a high concentration of specific antibody to the native capsular antigen of type Ia, group B Streptococcus, all sera tested had very low levels of type-specific antibody. All maternal sera had moderate to high bactericidal activity despite low specific antibody concentrations whereas $40 \%$ of neonates were deficient in functional bactericidal capacity (Fig. 1). Depression of bactericidal activity by these neonatal sera did not occur as the result of low specific antibody concentration, a finding which is consistent with the antibodyindependent mechanism of complement activation demonstrated previously for type Ia, group B streptococci $(2,8)$. 
The failure of selected specific antibody-deficient neonatal sera to recruit the alternative pathway when $\mathrm{Cl}$ was inactivated by MgEGTA chelation is consistent with previous studies employing adult sera (2) and suggests an absolute requirement of $\mathrm{Cl}$ for efficient bactericidal activity by low antibody-containing sera. In contrast, adult sera containing high concentrations of antibody to the type Ia, group B streptococcal capsular antigen recruit the alternative pathway in a manner analogous to that previously described for type III, group B streptococci (10). The absence of significant bactericidal activity after MgEGTA chelation of the single high antibody-containing neonatal serum is, therefore, a finding at variance with observations from other serum sources. It is possible that alternative pathway-mediated opsonic activity for type Ia, group B streptococci is also deficient in neonates, although conclusions cannot be drawn on the basis of the single serum available for study. Similarly, the significance of the lower levels of $\mathrm{H}$ in sera with low than those with high bactericidal indices is unknown.

The mechanism by which clinical isolates of type Ia, group B streptococci can activate $\mathrm{Cl}$ directly in the absence of antibody, leading to the formation of the classical $\mathrm{C} 3$ convertase $(\mathrm{C} 4 \mathrm{~b} 2 \mathrm{a})$ and cleavage of $\mathrm{C} 3$, is elucidated incompletely. The calcium dependence of the opsonization process has been shown by experiments in which dilution of agammaglobulinemic serum in MgEGTA resulted in bacterial growth (8). Although calcium concentrations were not determined for the normal neonates in the present studies, the possibility that a portion of these infants might have had subclinical hypocalcemia was considered, and the minimal essential media employed for these experiments, which contains $265 \mathrm{mg} /$ liter calcium chloride was selected to provide an excess of calcium ions. A role for $\mathrm{C} 2$ in antibody-independent activation has been demonstrated employing human serum genetically deficient in C2 (C2D), which also was deficient in specific antibody $(<2 \mu \mathrm{g} / \mathrm{ml})$. Genetically $\mathrm{C} 2$-deficient serum promoted bacterial growth, but bactericidal activity was restored after reconstitution of this serum with either human or guinea pig C2 (2). A requirement for classical pathway components $\mathrm{C} 4$ and $\mathrm{Cl}$ for opsonization has been shown by demonstrating consumption of C4 and efficient $\mathrm{C} 1$ transfer by strain 515 of type Ia, group B Streptococcus (8); therefore, the finding that deficient bactericidal activity by a portion of neonatal sera was associated with low levels of $\mathrm{Clq}$ and $\mathrm{C} 4$ supports the concept that a sufficient concentration of each of the components required to form the classical pathway convertase is required for opsonization.

The finding that FFP, which provided an antibody-deficient complement source itself promoted bactericidal activity and at low concentrations restored bactericidal activity to neonatal serum that had no intrinsic bactericidal activity suggested that the deficient bactericidal activity observed for a portion of neonates was not due to an inhibitor of complement activity. Furthermore, the in vitro restoration of efficient bactericidal activity for type Ia, group B Streptococcus at concentrations of fresh frozen plasma which could be achieved readily in vivo has obvious therapeutic implications.

The results of the present studies demonstrate a correlation between low levels of classical complement components Clq and $\mathrm{C} 4$ and deficient functional classical pathway activity. It is possible that for some neonates, an accentuation of a physiologic deficiency of one or more complement components enhances the suscepti- bility of these hosts to infections in which the classical complement pathway is required for opsonization.

\section{REFERENCES AND NOTES}

1. Adinolfi, M.: Levels of two components of complement $\left(C^{\prime} 4\right.$ and $\left.C^{\prime} 3\right)$ in human fetal and newborn sera. Develop. Med. Child Neurol., 12: 306 (1970).

2. Baker, C. J., Edwards, M. S., Webb, B. J., and Kasper, D. L.: Antibodyindependent classical pathway-mediated opsonophagocytosis of type Ia, group B Streptococcus. J. Clin. Invest., 69: 394 (1982).

3. Betz, S. J., Page, N., Estrade, C., and Isliker, H.: The effect of specific antibody on antibody-independent interactions between $E$. coli $\mathrm{J} 5$ and human complement. J. Immunol., 128: 707 (1982).

4. Betz, S. J. and Isliker, H.: Antibody-independent interactions between Escherichia coli J5 and human complement components. J. Immunol., 127: 1748 (1981).

5. Clas, F. and Loos, M.: Antibody-independent binding of the first component of complement $(\mathrm{Cl})$ and its subcomponent $\mathrm{Clq}$ to the $\mathrm{S}$ and $\mathrm{R}$ forms of Salmonella minnesota. Infect. Immunol., 31: 1138 (1981).

6. Davis, C. A., Vallota, E. H., and Forristal, J.: Serum complement levels in infancy: age related changes. Pediatr. Res., 13: 1043 (1979),

7. Drew, J. H. and Arroyave, C. M.: The complement system of the newborn infant Biol. Neonate, 37: 209 (1980).

8. Eads, M. E., Levy, N. J., Kasper, D. L., Baker, C. J., and Nicholson-Weller, A.: Antibody independent activation of $\mathrm{Cl}$ by type Ia group B Streptococcus. J. Infect. Dis., 146: 655 (1982)

9. Edwards, M. S., Baker, C. J., and Kasper, D. L.: Opsonic specificity of human antibody to the type III polysaccharide of group B Streptococcus. J. Infect. Dis., 140: 1004 (1979).

10. Edwards, M. S., Nicholson-Weller, A., Baker, C. J., and Kasper, D. L.: The role of specific antibody in alternative complement pathway-mediated opsonophagocytosis of type III, group B Streptococcus. J. Exp. Med., 151: 1275 (1980).

11. Fireman, P., Zuchowski, D. A., and Taylor, P. M.: Development of human complement system. J. Immunol., 103: 25 (1969).

12. Fishel, C. W. and Pearlman, D. S.: Complement components of paired mothercord sera. Proc. Soc. Exp. Biol. Med., 107: 695 (1961).

13. Loos, M., Wellek, B., Thesen, R., and Opferkuch, W.: Antibody-independent interaction of the first component of complement with gram-negative bacteria. Infect. Immunol., 22: 5 (1978).

14. Mancini, G., Carbonara, A. O., and Heremans, J. F.: Immunochemical quantitation of antigens by single radial immunodiffusion. Immunochemistry, $2: 235$ (1965).

15. Mayer, M. M.: Complement and complement fixation. In: E. A. Kabat and M. M. Mayer: Experimental Immunochemistry. p. 133 (Charles C. Thomas, Co., Springfield, 1961)

16. Mills, E. L., Björksteń, B., and Quie, P. G.: Deficient alternative complement activity in newborn sera. Pediatr. Res., 13: 1341 (1979).

17. Stossel, T. P., Alper, C. A., and Rosen, F. S.: Opsonic activity in the newborn: role of properdin. Pediatraics, 52: 134 (1973).

18. Strunk, R. C., Fenton, L. J., and Gaines, J. A.: Alternative pathway of complement activation in full term and premature infants. Pediatr. Res., 13: 641 (1979).

19. Tannous, R., Spitzer, R. E., Clarke, W. R., Goplerud, C. P., and CavendarZylich, N. Decreased chemotactic activity in activated newborn plasma. Role of higher chemotactic factor inactivator activity and lower complement levels. J. Lab. Clin. Med., 99: 331 (1982)

20. Winkelstein, J. A., Kurlandsky, L. E., and Swift, A. J. Defective activation of the third component of complement in the sera of newborn infants. Pediatr. Res., 13: 1093 (1979)

21. The authors thank Roxanna Krafka for assistance in the collection of sera, Bette J. Manulik and Connie M. Schimbor for technical assistance, Dixie Hargraves for secretarial assistance and Ralph D. Feigin for review of the manuscript.

22. Recipient of Research Career Development Award K04 AI00323 from the National Institute of Allergy and Infectious Diseases.

23. Requests for reprints should be addressed to: Dr. Morven S. Edwards, Department of Pediatrics, Baylor College of Medicine, 1200 Moursund Avenue, Houston, Texas 77030

24. This research was supported in part by the Myers-Blacḱ Mellon Enterprises Pediatric Infectious Diseases Research Fund and by grant AI 13249 from the National Institute of Allergy and Infectious Diseases.

25. Received for publication August 26, 1982

26. Accepted for publication January 4, 1983 